\title{
Structural and Chemical Controllers of the North and Northwest of Torud Based on Involved Fluid Studies, Structural and Geochemical Analyses
}

\author{
Fatemeh Baseri, Arash Gourabjeri Pour, Nima Nezafati
}

\begin{abstract}
Chah Mura mining area in Semnan province is located $30 \mathrm{~km}$ southwest of Shahroud and $20 \mathrm{~km}$ north of Torud village with an area of $35 \mathrm{~km} 2$ and includes a part of 1:250,000 Torud plate. Structurally, this area is located in the northeastern part of Central Iran and in the center of the volcanic-intrusive arc of Torud-Chah Shirin. Rock units of the area are volcanic and pyroclastic, depending on the Eocene age. Exposed assemblages in the Chah Mura area, based on field and laboratory studies, can be divided into basalt, andesite, andesite-basalt, trachyandesite, trachyandesibasalt and small outcrops of pyroclastic units in the form of agglomerates and sediments of sandstone and conglomerate. Volcanic rocks are influenced by sub-volcanic masses younger than Eocene with an intermediate to basic composition, and their predominant textures are granular, porphyroid with microcrystalline to microintragranular background. Finally, the units are cut by dikes. In this area, mineralization is mainly in the control of sub-faults and subvolcanic massifs. Mineralization is in the form of vein-veinlet, filling empty and scattered space in the oxidation-supergen stage. Mineral sequences include pyrite, chalcopyrite, chalcocite, digenite and covellite, cuprite, tenorite, natural copper, malachite, azurite, and iron oxides and hydroxides. Geochemical studies indicate that copper does not correlate well with any of the base metals and depositing elements. Copper shows only a relative correlation with silver. Micrometric studies of fluid inclusions in samples from this area indicate dilution as a result of mixing hydrothermal solutions with atmospheric fluids in formation of this reserve.
\end{abstract}

Keywords: Calc-Alkaline; Chah Mura; isotopic analysis; mineralization; subvolcanic

\section{INTRODUCTION}

Paying attention to the mining sector and related industries is one of the economic priorities of developing countries. Therefore, recognizing the mineral potentials and exploration of mines has a very important role in large investments in industry and mining. Iran, with its various mineral potentials of base and precious metals, can be a suitable platform for exploration of such mines. Development of mining activities contributes significantly to production of wealth, job creation and eradication of poverty from deprived areas of the country. It should be noted that in Iran, a large part of the mineral reserves is still unknown, and in this regard, research on known reserves can help us understand the conditions of deposit formation and be a key to explore unknown mineral reserves in similar formation conditions. Geochemistry is a science that deals with distribution and migration of geochemical elements within the earth [1]. One of the most important aspects that is usually considered in geochemical studies is how different elements are distributed and dispersed in rock units of each region and relationship of these elements with each other. Using these relationships, it is possible to understand to some extent the characteristics of formation environment and effective processes in formation of deposits [2]. Geochemistry is discussed in two parts: geochemistry of mineral rocks (in terms of main and secondary elements) and geochemistry of element or deposit elements in the mineralization zone. Understanding the conditions and formation of deposits is one of the main topics of economic geology and study of fluids involved can provide us with comprehensive and complete information in these areas. Each inclusion is the result of trapping a small volume of mineralizing fluid within the crystal and may be composed of magmatic, atmospheric, or compressed gas fluids. These inclusions are unique signs that, because they do not change over geological times, can indicate temperature, fluid salinity, chemical composition, and ambient pressure. Although other methods, such as studying the paragenesis of minerals and studying their texture, can be used to determine the temperature and composition of the solution and the mineralizer, the study of the fluids involved is superior to other methods in terms of accuracy and speed.

\section{GEOGRAPHICAL LOCATION AND ACCESS ROADS}

The studied area is in the north and northwest of Torud (between the geographical coordinates $54^{\circ} 58^{\prime} 15^{\prime \prime}$ east longitude and $35^{\circ} 34^{\prime} 20^{\prime \prime}$ north latitude up to $55^{\circ} 00^{\prime} 14^{\prime \prime}$ east longitude and $35^{\circ} 34^{\prime} 20^{\prime \prime}$ north latitude) and includes the mineral area of Chah Mura copper in Semnan province and is located $130 \mathrm{~km}$ southwest of Shahroud and $100 \mathrm{~km}$ southeast of Damghan with the geographical coordinates $54^{\circ} 58^{\prime} 14^{\prime \prime}$ to $55^{\circ} 01^{\prime} 20^{\prime \prime}$ east longitude and $35^{\circ} 36^{\prime} 00^{\prime \prime}$ to $35^{\circ} 37^{\prime} 21$ " north latitude and is located $20 \mathrm{~km}$ north of Torud. The studied area is located in the north of Torud, Shahroud. The access road to the area is through Shahroud-Torud road and with a distance of about $100 \mathrm{~km}$ from Shahroud to Torud and different parts of the area can be accessed by using side roads in the area.

\subsection{Position of the Studied Area in Structural Geology of Iran}

The studied area is located in the center of the Torud Mountains in northeastern Iran, is bounded on the north by the Alborz Mountains, and is separated from the Great Desert on the south by the Doruneh Fault. The Torud Mountains located in the structural zones of Iran is part of the Central Iran zone [3] and in the northern part of the Central Iran zone [4] (Fig. 1). According to Alavi [5], this area is located in the magmatic complex of eastern Iran and in the Sabzevar zone. In classification of Nogol Sadat and Almasian [6], this area 
is located in the tectonic-sedimentary unit of Central Iran, its northern half and below the central magmatic section. According to Shamanian et al. [7], this arc is considered to be part of the Alborz magmatic arc. Houshmandzadeh [8] consider this mountain range as a part of the Urmia-Dokhtar magmatic arc, from which it has been separated due to an inter-arc tension in the late Eocene. The arc is bounded on the north by the Anjilo fault and on the south by the Torud fault, and the mountain ranges and faults have an approximate trend of $\mathrm{N} 70^{\circ} \mathrm{E}$; on the northern edge, there is the fall of the Great Desert.

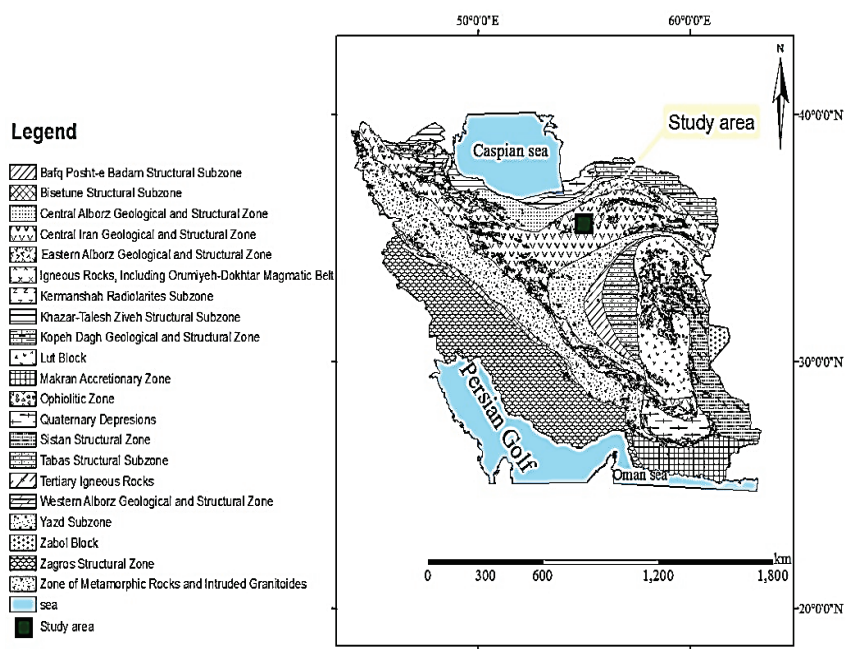

Figure 1 Location of the studied area in the map of structural-sedimentary zones in Iran

\subsection{General Stratigraphy of Torud Area}

The oldest rocks in the area are precambrian gneisses, amphibolites and micaschists. From Cambrian to Devonian, the metamorphic equivalents of niur formation, Padha, Sibzar and Bahram can be seen. Paleozoic rock units are less widespread in the area and include limestone, dolomite limestone, dolomite, gneiss, amphibolite, and schist, which have also undergone low-grade compressive-thermal metamorphism (up to green schist facies). These rocks have recrystallized and at least one metamorphic foliation has occurred in them. The oldest exposed rocks are metamorphic rocks which are given Paleozoic age in Kalateh Rashm based on stratigraphic sequences. These rocks, which are mostly crushed and cut, have been affected by Eocene-Oligocene magmatic masses and their hydrothermal fluids. Therefore, there are signs of concentration of metal ores, especially iron oxides in the joints and cavities of their carbonate rocks.

Mesozoic deposits in the studied area include only Late Cretaceous limestone-shale and sandstone units that have formed in a marine sedimentary environment and have been exposed in the northwestern to western parts of the plate (Figs. 2-3). Cenozoic deposits begin mainly with Lower Eocene volcanic activities and have produced large volumes of igneous-sedimentary materials during the Paleogene. These materials have appeared in the form of various stone units. Cenozoic deposits are characterized by the highest magmatic activity in the area and have left a large volume of igneous rocks during the Early Tertiary (Eocene-Oligocene). Post-Pleistocene deposits are mostly seen as old terraces. Neogene deposits are not visible below the Torud-Chah Shirin zone, and non-hardened destructive and foothill deposits can be seen only at the end of the Neogene and at the beginning of the Quaternary. However, under the Jandagh zone, a large amount of very low-depth marl deposits and gypsum sandstones have been deposited during the Neogene period. In the Torud area, Quaternary deposits are limited to the deeper parts of the desert. Flood rivers in these parts are relatively thin, covered with mud and sand, and in some places the evaporation of these waters has left pure salt. Quaternary deposits are generally thin and the basins are not very shallow. These deposits include old and young alluvial terraces and alluvial fans, mudflats, sand dunes and deserts (clay and saline sediments).

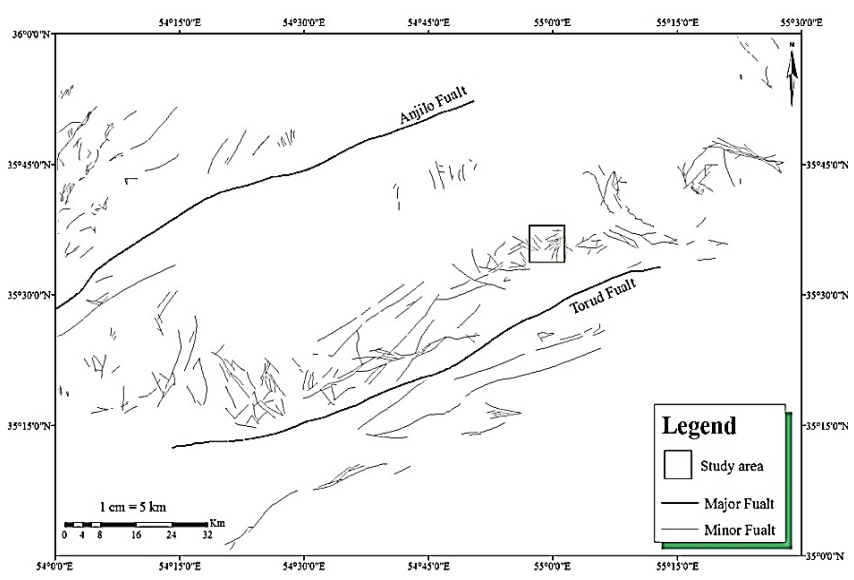

Figure 2 Map of major and minor faults in Torud area and location of the mineral area on it

\subsection{Magmatism}

Iran, as part of the central-western regions of the AlpineHimalayan orogenic system, has undergone extensive magmatic (volcanic and intrusive) activity, especially during the Cenozoic period, due to special tectonic structure of the convergence zones [5, 9-12]. Geological and magmatic maps [13] of Iran have well reflected the severity and importance of this event and also show that the widespread Cenozoic magmatism is irregularly distributed throughout Iran, so that numerous volcanic-intrusive chains can be imagined throughout Iran. The Torud area has witnessed magmatic activity since the earliest geological times. These activities started in the first and second periods due to small tectonic events and peak in Tertiary. Magmatic activity in the area begins during the Silurian period, which is accompanied by the release of andesitic lavas. Hooshmandzadeh et al. [8] consider this activity to be related to early Silurian Epirogenic movements. The magmatic activities of the second period are not widespread in the area of Torud. Tertiary is a period of extensive magmatic activity of which products (tuff, lava, and intrusive masses) cover the entire area. 


\subsection{Tectonics}

Hooshmandzadeh et al. [8] divided tectonic movements in Torud area into three periods:

\subsubsection{Tectonic Movements of the First Period}

The movements of this period mostly show the state of epeirogenic movement; the first movements in the late Ordovician caused the Silurian sea floor to rise, and continued to rise regularly until the late Devonian. During the Middle Devonian period, the sea receded again which continued until the end of the Devonian. In the early Carboniferous period, the Torud area suddenly emerged from the water and in the Permian the sea advanced again, but at the end of this period some parts emerged from the water.

\subsubsection{Tectonic Movements of the Second Period}

The most important movements of this period can be divided into four phases:

A) The phase between Middle Triassic-Late Triassic (Early Kimmerian): This phase is mostly epeirogenic movment in the area where piezolite horizons, iron oxides and alumina on permutriassic dolomites can be the result of the operation of this phase [5].

B) The phase between Lias-Dogger: The result of the operation of this phase in the area is eprieogenic movements with short and insignificant amplitudes; conglomerate of the Middle Jurassic base and andesitic lavas in the north of Sahl, Mit and Andes village indicate the operation of this phase.

C) The phase between Late Jurassic-Early Cretaceous (Late cambrian): This phase is the most important phase in terms of folding. In the volcanoplotonic belt of Torud, folding along with dynamothermal metamorphism is the result of the operation of this phase.

D) Cretaceous phases: The Cretaceous movement in the Torud area includes the following:

- The sea precedes in the lower Cretaceous.

- The sea recedes from the middle Albian and the area emerges from the water in the Cenomanian area.

- In Turonian, the sea is advancing again.

- From Coniacian, the sea recedes and in Maastrichtian this area emerges from the water.

\subsubsection{Tertiary Tectonic Movements}

Tertiary dynamic activity is studied in two parts:

A) Movements after Cretaceous and before Eocene (Laramide phase)

B) Middle tertiary movements-posterior tertiary

\subsection{Dynamic Components \\ 2.5.1 Faults}

In the north of Torud, a group of main faults have affected the Torud area. The most important of these faults are Torud fault and the other is Anjilo fault which is located in the north of Torud fault. The trend of these faults is N-60$70 \mathrm{E}$ and they have a slope of about 80 degrees to the south [3]. Because these faults have been active for long periods of time and many times, it is not possible to determine their exact movement. Although the trend of these faults is Caledonian trend, Hooshmandzadeh et al. [8] believe that these faults, at least from the Cambrian onwards, have affected the area. Torud fault is in fact a fault with northeastsouthwest trend that in Sabzevar region has caused the separation of Sabzevar melange ophiolites from the desert zone. The mechanism of this fault is left-handed landslide. This fault has caused severe deformation in the region and is one of the oldest faults in Iran. This fault has changed many sedimentary facies in the distance between Kavir and Sabzevar. Due to scratches seen on the fault planes, these faults have two directions [14]. The Torud earthquake was associated with moving along the fault along the east, northeast (reactivation of the Torud fault). One of the plates obtained from solution of the focal mechanism by Shirokova [15] corresponds well with the rupture caused by earthquake and shows a sloping fault to the south, the southern block of which is pushed upwards and has a right-handed small horizontal component [16]. Anjilo fault with an almost northeast-southwest trend is seen in the south of the structural zone of the eastern Semnan. Khademi et al. [17] introduced this fault as parallel and similar to Torud fault and introduced it as left-slip landside. In the south of this fault, there is Torud fault with left slip landside, which has been active in terms of seismicity.

\subsection{Mineral Potentials of Torud}

The mineral rang in question is part of the field metallurgy gold-polymetallic of Torud. This area is in fact a volcanic-intrusive magmatic arc of the Tertiary (Eocene, Oligocene, Mio-Pliocene), which is present on the Precambrian and Paleozoic metamorphic belt in a band extending approximately east-west in the northern margin of the Great Desert, which is one of the potential axes in terms of mineralization and metal and non-metal mines in which mining activities have long flourished. The presence of abundant metal deposits such as lead and zinc, copper, iron, gold and turquoise and non-metallic deposits such as bentonite, feldspar, fireclay and industrial soils confirm the high potential of mineralization. This complex, which consists of volcanic rocks with a predominant andesitic composition and granodiorite masses with a predominantly diorite composition, hosts numerous vein deposits of base metals and gold $[18,19]$. So far, no evidence of porphyry copper mineralization has been seen in this arc and it is the predominant form of vein metal deposits [20]. In the report of Iranian copper reserves, copper deposits of the area are vein type deposits [21]. Among the important copper deposits, one can mention Chah Musa mine, Chah Gale and lead and zinc deposits of Khanjar, Abolhassani, Cheshmeh Hafez and Gandi gold deposits, Darestan index, etc. (Fig. 3). 


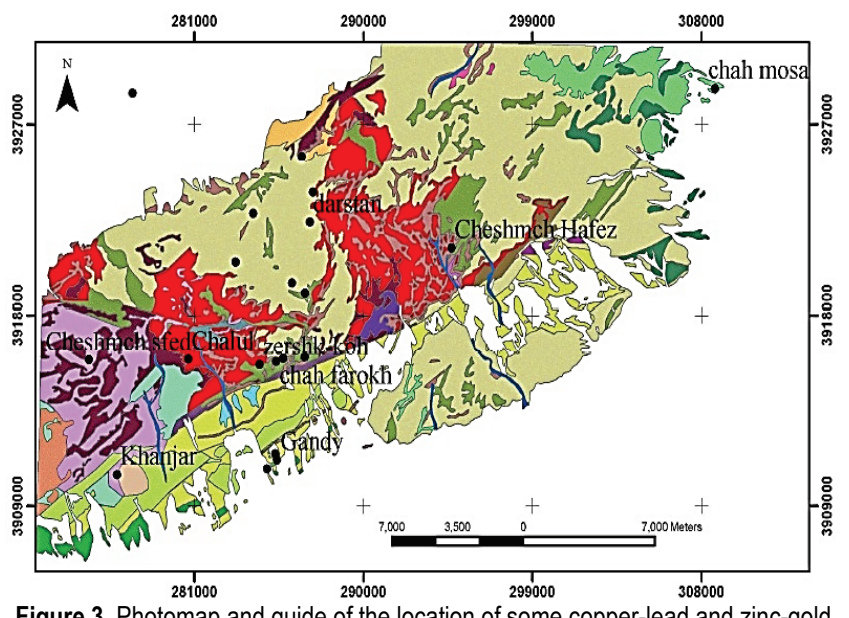

Figure 3 Photomap and guide of the location of some copper-lead and zinc-gold deposits in volcanic-intrusive arc of Torud-Chah Shirin

\section{GEOCHEMICAL PROPERTIES OF ROCKS}

In order to carry out geochemical studies, including designation, determination of magmatic series, tectonic site and spider diagrams for trace elements, 15 samples of mineralization-related rocks in Chah Mura area with minimal alteration were prepared for XRF analysis and sent to the wet chemistry laboratory of the Geological Survey and Mineral Explorations of Iran.

\subsection{Classification and Designation of Volcanic Rocks}

\section{A) TAS classification (total alkali versus silica)}

Oxide-oxide two-variable diagrams of main elements are probably the most direct way to classify igneous rocks. Today, however, this method is more suitable for volcanic rocks. One of these diagrams is in total alkali diagram $\left(\mathrm{Na}_{2} \mathrm{O}\right.$ $+\mathrm{K}_{2} \mathrm{O}$ ) in $\mathrm{SiO}_{2}$. Rare elements are also used versus $\mathrm{SiO}_{2}$. The results show that volcanic rocks fall into the combined domain of basalt-hawaiite-mugearite-trachyandesite-basalt andesite-andesite and composition of the rocks is between the basic to the intermediate. Volcanic rocks fall into the combined domain of basalt-trachyandesite-trachyandesite basalt-andesite basalt-andesite. Since mineralogical and chemical alternations are higher in endogenous igneous rocks due to the possibility of alternation in volcanic rocks, they can be designated using elements that are less mobile. The most important of these elements are $\mathrm{Nb}, \mathrm{Y}, \mathrm{Zr} / \mathrm{TiO}_{2}$ and $\mathrm{Ga}$ [22].

\section{B) Chemical classification based on trace element}

In these diagrams, the vertical axis of which is based on silica and the horizontal axis of which is based on logarithmic ratio $\mathrm{Zr} / \mathrm{TiO}_{2}$, the results showed that volcanic rocks fall into hybrid domain of andesite-andesite basalt-latite to latite andesite-mugearite and dikes into mugeandesite domain. The results showed that most of the samples are on the trachyandesite-alkali basalt boundary. The samples show more traction towards the trachyandesite and can confirm the separation process from a mafic parent magma.

\subsection{Determination of Magmatic Series}

In a given volcanic region, lavas have pieces of similar chemical properties that are assigned to the same region. The study of magmatic series effectively contributes to understanding the magmatic and lithological developments of a region. The gradual evolution of chemical and mineralogical composition from one lava to another is a sign of the kinship of the lavas and their origin from a common source. According to Kuno [23] theory, a magmatic series is a collection of different igneous rocks that have different chemical compositions and are obtained by subtraction from an early basic magma. However, it has recently become clear that in addition to partial crystallization, the melting mechanism of magma mother rock can also lead to igneous rock diversity. Diagrams were used to determine the magmatic series (Fig. 4).
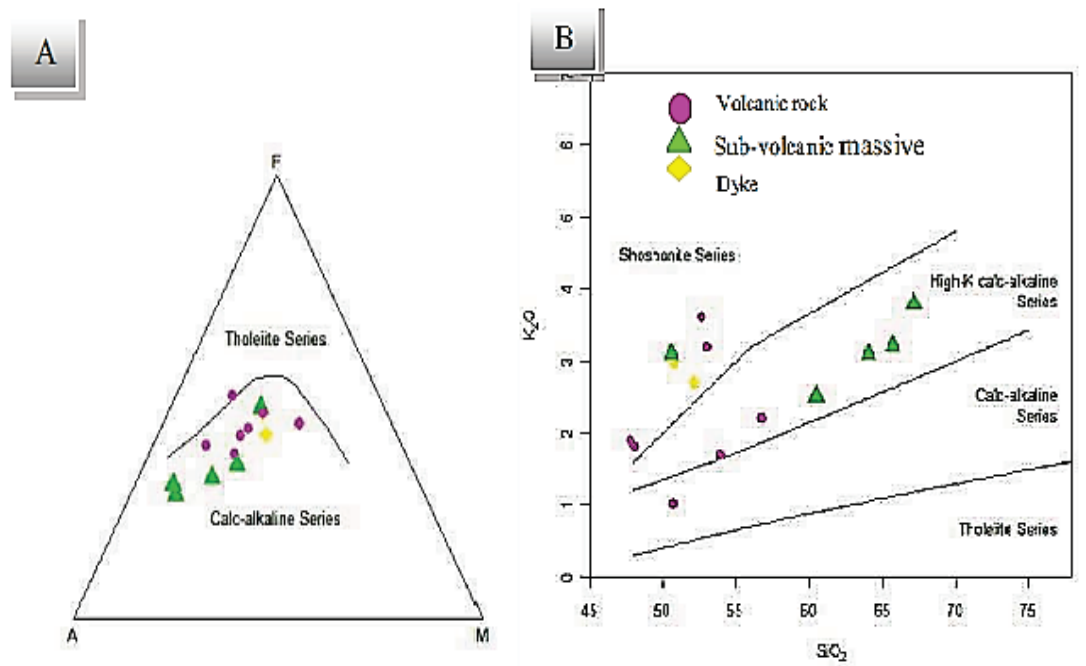

Figure 4 Diagrams of magmatic series determination 


\section{AFM diagram}

According to these diagrams, location of subvolcanic rocks and volcanic rocks in the area are within the range of calc-alkaline series.

\section{$\mathrm{K}_{2} \mathrm{O}$ vs. $\mathrm{SiO}_{2}$ diagram}

According to these diagrams, location of subvolcanic and volcanic rocks in the region range from calc-alkaline series to potassium-rich shoshonitic.

\section{Th vs. CO diagram}

This diagram is introduced for areas affected by alteration in order to reduce the alteration effects in petrological studies, in which $\mathrm{CO}$ substituting $\mathrm{ThSiO}_{2}$ replaces $\mathrm{K}_{2} \mathrm{O}$ and the mentioned ratios replace AFM. According to these diagrams, the sub-volcanic rocks and volcanic rocks of the area range from calc-alkaline series to potassium-rich shoshonite.

\section{TECTONIC SITE OF ROCK}

Geochemical detection diagrams were widely used in the late 1970 s and early 1980 s to identify tectonic sites of igneous rocks. Obviously, these diagrams can never be used to prove the presence of a tectonic environment, but these diagrams only show the possibility of a tectonic environment [24]. Trace elements and major elements are used by many researchers to detect tectonic environments. Among them, Y, $\mathrm{Tb}, \mathrm{Nb} \mathrm{Th} / \mathrm{Yb}, \mathrm{Ta} / \mathrm{Yb}$ elements are very important due to their low mobility during magmatic rock formation processes such as subduction phenomenon [25-27] (Fig. 5).

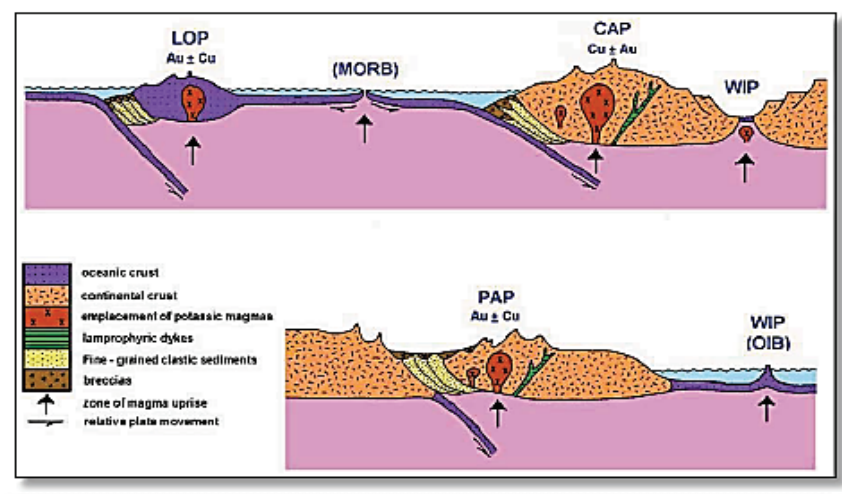

MORB $=$ Mid Oceanic basalt PAP $=$ Post Collisional Arc WIP $=$ Within plate setting $\quad$ LOP $=$ Late Oceanic Arc $\mathrm{OIB}=$ Oceanic Island Basal $\quad$ LOP $=$ Initial Oceanic Arc

Figure 5 View of some important tectonic sites in formation of igneous rocks and associated deposits (Mitchell \& Garson)

\subsection{Study of Geochemical Properties of Copper Element in the Area of Chah Mura}

Copper is a chalcophile element, its average value in the Earth's crust is $55 \mathrm{ppm}$. It is a metal in the group of intermediate elements. In monovalent state, this metal is similar to precious elements such as gold and silver, and in divalent state, it is similar to other metals of the first group of intermediate elements such as $\mathrm{Ni}, \mathrm{Co}$ and $\mathrm{Fe}$. Because copper is a chalcophile element, it rarely produces silicate minerals, although alteration of primary sulfides results in formation of secondary minerals such as oxides, carbonates, and silicates.

\subsection{Distribution and Abundance of Elements Related to Mineralization}

Examining the abundance and distribution of major, minor and trace elements in rock mass to investigate the behavior of one element and its relationship with other elements can be useful for development of exploration methods for similar deposits. In order to know the distribution and abundance of elements, especially copper, and determine their correlation coefficient with associated mineralizing elements, 20 lithogeochemical samples were taken from units related to mineralization for ICP-OES analysis and sent to chemical laboratory in the Geological Survey and Mineral Explorations of Iran. Finally, according to the results of analysis and petrography and field observations, the following units are described in terms of the importance of copper mineralization. SPSS and Excel software were used to process and analyze the data.

\subsection{Distribution and Abundance of Elements in the Andesitic Unit (EAN)}

In order to understand distribution and abundance of copper, 5 samples of mineralized and non-mineralized rocks were taken from this unit and studied and the results are given in Tab. 1. Due to the faulting as well as injection of subvolcanic masses, small fractures were created in the mineralized zones and the main factor for concentration of copper in the fractures was in the form of vein-veinlet and sulfide type spray. Alterations such as silicification, carbonation, oxidation and argillization have been implicated in copper deposit. In this unit, maximum amount of copper is equal to $21760 \mathrm{ppm}$ which was measured in sample EB-5 and its minimum amount is equal to $65 \mathrm{ppm}$ in the nonmineralized part. The presence of metal minerals such as chalcopyrite and chalcocite, etc. in this unit shows the importance of mineralization. Maximum amounts of sulfur and barium are $1176 \mathrm{ppm}$ and $742 \mathrm{ppm}$, respectively. The amount of other base metals (lead and zinc) in this unit is relatively low. The low levels of these elements should be attributed to mobility of these elements during hydrothermal alteration [28] or the difference in their transport by hydrothermal fluids [29]. Maximum levels of silver (Ag) and arsenic (As) are 4 ppm and 3 ppm.

\subsection{Distribution and Abundance of Elements in Tracyandesitic Unit (Eta)}

In order to understand distribution and abundance of copper, 7 samples were taken from this unit and studied and the results.

There are many sub-faults and fractures in this unit, which are the main factor for operation of hydrothermal 
fluids and ultimately cause alteration in the unit rocks. Based on field, microscopic, and XRD observations, alterations such as chlorination, carbonation, iron oxide and hydroxides, predominant argillization, and low silicification are present. In the tracyandesitic unit, the element copper has a value of 13408 ppm, which was measured in the sample EB-23, and sulfur has a maximum value of $322 \mathrm{ppm}$ and minimum amount of copper in this unit is equal to $76 \mathrm{ppm}$ in the altered part of the sample EB-41. The element barium in this unit has a maximum value of $1030 \mathrm{ppm}$, which was measured in sample EB-29, and its minimum value is equal to $248 \mathrm{ppm}$ in sample EB-33. Other elements, such as lead and zinc, are not abundant. In the study of polished sections of these samples, copper minerals such as chalcocite, malachite, atacamite, tenorite along with hematite and goethite were observed that the presence of these minerals is consistent with the results of analysis. The maximum levels of silver (Ag) and arsenic (As) are $1.3 \mathrm{ppm}$ and $8 \mathrm{ppm}$.

Table 1 Statistical parameters of $\mathrm{Cu}, \mathrm{Mo}, \mathrm{Pb}, \mathrm{Zn}, \mathrm{Ba}, \mathrm{S}, \mathrm{Ag}$ elements in the andesitic unit

\begin{tabular}{|c|c|c|c|c|c|c|c|c|c|c|}
\hline \multicolumn{11}{|c|}{ Statistic } \\
\hline & & $\mathrm{CU}$ & $\mathrm{Mn}$ & $\mathrm{Pb}$ & $\mathrm{Zn}$ & $\mathrm{Ag}$ & As & Mo & $\mathrm{S}$ & $\mathrm{Ba}$ \\
\hline \multirow{2}{*}{$\mathrm{N}$} & Valid & 5 & 5 & 5 & 5 & 5 & 5 & 5 & 5 & 5 \\
\hline & Missing & 0 & 0 & 0 & 0 & 0 & 0 & 0 & 0 & 0 \\
\hline \multicolumn{2}{|r|}{ Mean } & 4522 & 1039 & 35 & 81 & .1 & 2 & 2 & 595 & 522 \\
\hline \multicolumn{2}{|r|}{ Median } & 170 & 851 & 37 & 79 & .1 & 2.5 & 2 & 517 & 499 \\
\hline \multirow{2}{*}{\multicolumn{2}{|c|}{$\begin{array}{c}\text { Mode } \\
\text { Minimum }\end{array}$}} & 65 & 793 & 22 & 67 & .1 & 1 & 2 & 188 & 371 \\
\hline & & 65 & 793 & 22 & 67 & .1 & 1 & 2 & 188 & 371 \\
\hline \multicolumn{2}{|r|}{ Maximum } & 21760 & 1696 & 50 & 90 & 4 & 3 & 8 & 1176 & 742 \\
\hline
\end{tabular}

Table 2 Statistical parameters of $\mathrm{Cu}, \mathrm{Mo}, \mathrm{Pb}, \mathrm{Zn}, \mathrm{Ba}, \mathrm{S}$, Ag elements in subvolcanic masses

\begin{tabular}{|c|c|c|c|c|c|c|c|c|c|c|}
\hline \multicolumn{11}{|c|}{ Statistic } \\
\hline & & $\mathrm{CU}$ & $\mathrm{Mn}$ & $\mathrm{Pb}$ & $\mathrm{Zn}$ & $\mathrm{Ag}$ & As & Mo & $\mathrm{S}$ & $\mathrm{Ba}$ \\
\hline \multirow{2}{*}{$\mathrm{N}$} & Valid & 8 & 8 & 8 & 8 & 8 & 8 & 8 & 8 & 8 \\
\hline & Missing & 0 & 0 & 0 & 0 & 0 & 0 & 0 & 0 & 0 \\
\hline \multicolumn{2}{|r|}{ Mean } & 211 & 865 & 35 & 80 & .1 & 3 & 2 & 377 & 869 \\
\hline \multicolumn{2}{|r|}{ Median } & 171 & 812 & 34 & 83 & .1 & 3 & 3 & 347 & 622 \\
\hline \multirow{2}{*}{\multicolumn{2}{|c|}{$\frac{\text { Mode }}{\text { Minimum }}$}} & $81 \mathrm{a}$ & $264 a$ & $23 a$ & $37 \mathrm{a}$ & .1 & $1 \mathrm{a}$ & 3 & $214 \mathrm{a}$ & $453 \mathrm{a}$ \\
\hline & & 81 & 264 & 23 & 37 & .1 & 1 & 1 & 214 & 453 \\
\hline \multicolumn{2}{|r|}{ Maximum } & 707 & 1713 & 45 & 111 & .5 & 7 & 4 & 144 & 2743 \\
\hline \multicolumn{2}{|r|}{ Sum } & 1688 & 6923 & 282 & 646 & 1 & 27 & 23 & 3019 & 6958 \\
\hline
\end{tabular}

\begin{tabular}{|c|c|c|c|c|c|c|c|c|c|}
\hline & Mineral & Position & Type & Origin & Size & $n$ & $\begin{array}{c}\text { Th } \\
\text { Total }(0 \mathrm{c})\end{array}$ & $\begin{array}{c}\text { Tm } \\
\text { Ice }(0 \mathrm{c})\end{array}$ & $\begin{array}{c}\text { Salinity } \\
\text { Aqwt } \% \text { Nacl }\end{array}$ \\
\hline KB-20 & Qtz & Cc-bearing Qtz vein & $\mathrm{L}+\mathrm{V}$ & $\mathrm{p}$ & $14 \times 5$ & 1 & 160 & -0.8 & 1.89 \\
\hline KB-29 & Cal & Cc-Mal-bearing Qtz vein & $\mathrm{L}+\mathrm{V}$ & $\mathrm{p}$ & $10 \times 6$ to $48 \times 16$ & 15 & 165 to 299 & -4.20 to -0.8 & 1.37 to 6.39 \\
\hline KB-24 & Qtz & Cc-Mal-bearing Qtz vein & $\mathrm{L}+\mathrm{V}$ & $\mathrm{p}$ & $9 \times 3$ to $48 \times 10$ & 15 & 165 to 317 & -4 to 5.8 & 0.99 to 7.07 \\
\hline $\mathrm{KB}-25$ & Cal & Cc-bearing Cal vein & $\mathrm{L}+\mathrm{V}$ & $\mathrm{p}$ & $11 \times 9$ to $80 \times 35$ & 8 & 221 to 330 & -4.2 to 5.6 & 3.39 to 7.07 \\
\hline KB-38 & $\mathrm{Cal}$ & Mal-bearing Cal vein & $\mathrm{L}+\mathrm{V}$ & $\mathrm{p}$ & $10 \times 4$ to $25 \times 24$ & 5 & 143 to 170 & -2.6 to 4.9 & 0.97 to 3.98 \\
\hline
\end{tabular}

\subsection{Distribution and Abundance of Elements in Subvolcanic Masses}

In order to understand the distribution and frequency of copper and the role of subvolcanic masses as one of the controllers of mineralization, 8 samples were taken and examined and the results are presented in Fig. 6 and Tabs. 2 and 3. Composition of the masses changes from intermediate to acidic. Its injection into volcanic units has caused many fractures in the area. Common alterations in them are: chlorite, silicification, carbonation clay and sericitization and are similar to mineralization host units. Copper minerals were not observed in this unit and only minerals such as pyrite, calcite, granular quartz, magnetite and hematite were seen in microscopic studies. The maximum amount of copper is equal to $707 \mathrm{ppm}$ which was measured in sample EB-4 from gabbro-porphyry diorite and the minimum amount of copper is equal to $81 \mathrm{ppm}$ from micro gabbro mass. In addition, the amount of barium and sulfur elements are 2743 ppm and 544 ppm, respectively. The presence of a high field of copper in subvolcanic masses can highlight their role in relation to potential source of copper; moreover, high amounts of sulfur and the presence of pyrite in these masses can be identified according to the results.

\section{FLUID INCLUSIONS}

\subsection{Petrography of Fluid Inclusions}

To study the fluids involved in Chah Mura area, 5 samples of quartz and calcite minerals in copper mineral veins that contained minerals were used. In order to determine the temperature, depth, pressure of the mineral fluid was selected. Considering the thin sections of the rock, it contains porphyry andesite. A number of the studied fluids involved in quartz and calcite are associated with minerals. Once the double polish sections were prepared, they were given to the relevant laboratory of fluid studies of the Geological Survey and Mineral Explorations of Iran in order to perform petrographic and thermometric studies (cooling and heating). PVTX Modeling for Fluid Inclusion V2.6 
software was used to determine the percentage of salinity and density of fluids and to draw diagrams.
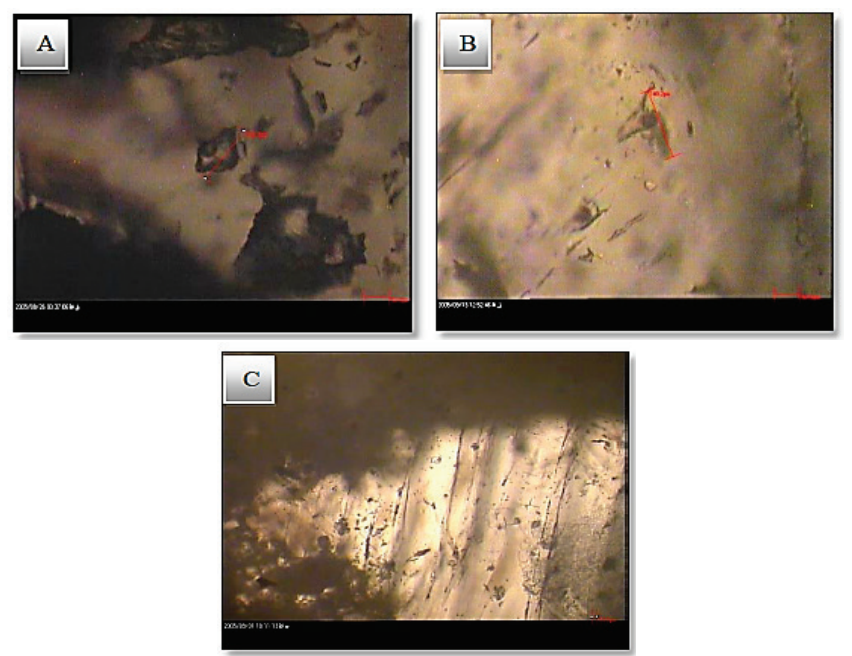

Figure 6 A and B: View of the fluid involved in the quartz mineral; C: View of the fluid involved in the mineral calcite

\subsection{Classification of Fluids Involved Based on Time and Origin of Formation}

In this classification, formation time of the involved fluids is measured relative to formation time of the crystal. In fact, this classification is a kind of classification based on the origin of the fluids involved. The classification proposed by Yermakov [30] and Shepherd [31] includes three types of fluids involved:

\subsection{Primary Inclusion}

This group of fluids is formed during crystal growth. These fluids are trapped by processes such as dendritic growth of crystal plates, spiral growth, semi-parallel growth, or partial dissolution of crystalline surfaces within these plates.

\subsection{Secondary Inclusion}

This group of involved fluids is formed after the crystallization is complete. One of the processes involved in formation of secondary fluids is the trapping of fluid at the fracture sites that occur after mineral formation [32].
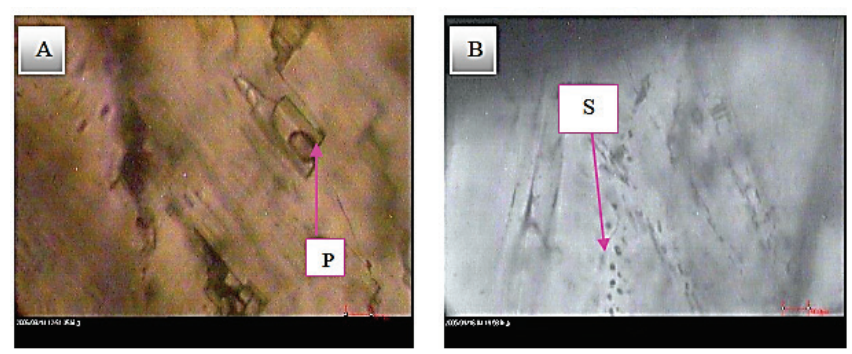

Figure 7 A view of primary fluid involved, indicated by $\mathrm{P}$

\subsection{Pseudosecondary Inclusion}

These fluids are formed during the crystallization of the mineral containing them, but some of their properties are similar to those of the secondary fluids involved. If the crystal cracks during crystal growth due to phenomena such as tectonic stress, the mineralizing fluids can concentrate at the crack site and give rise to pseudosecondary fluids (Fig. $7)$.

\section{THERMOMETRY}

The thermometry studies, which are performed in order to determine the homogeneity temperature of inclusions and determine the chemical composition, particularly fluid salinity, is based on destructive and non-destructive methods. In non-destructive methods, the inclusions are heated in order to determine the degree of homogeneity without damaging the internal content of the inclusions, and they are frozen in order to determine the salinity of the fluids [33]. Thermobarometric measurements were performed on two different types of A-B. It was not possible to measure in single-phase fluids involved.

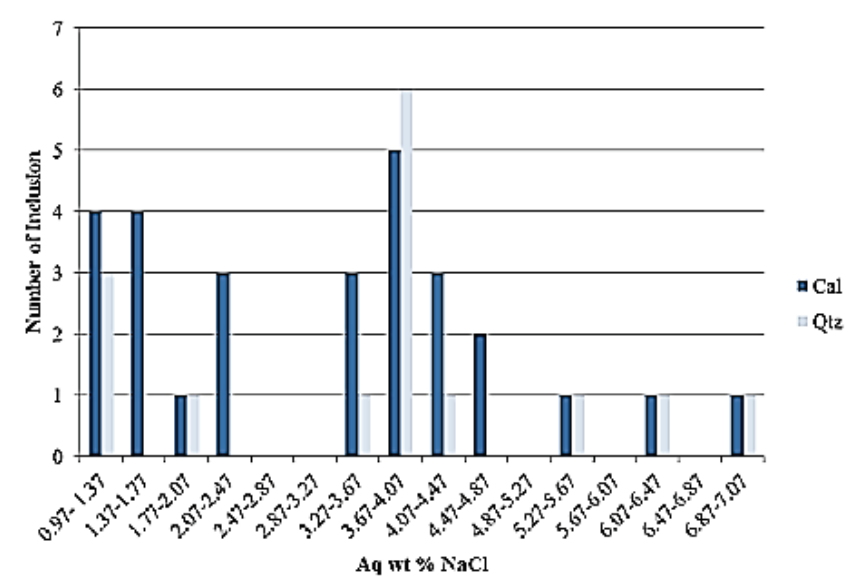

Figure 8 Bar chart measuring salinity changes (\% Wt NaCl versus frequency

\section{FREEZING}

By measuring changes in freezing degree, salinity and density can be measured in the fluids involved. The first temperature recorded was during the formation of the first melting drop $\left(T_{\mathrm{e}}\right)$ or eutectic point temperature. The eutectic temperature, $T_{\mathrm{e}}$, is lower than $-20{ }^{\circ} \mathrm{C}$ in some of the studied samples, which indicates the presence of salts other than $\mathrm{NaCl}$ in the mineralizing fluid, the ice melts gradually until the last ice crystal disappears. The last temperature recorded during melting is called $T_{\mathrm{m}}$ temperature. Using $T_{\mathrm{m}}$, the fluid salinity can be determined. In the studied samples, salinity $\mathrm{WtNaCl} \%$ and density were calculated by PVTX modeling software, Linkam. The information is presented in the form of tables and histogram models. The last ice crystals in these inclusions are melted at +6 to $-4.20{ }^{\circ} \mathrm{C}$ and the highest number of samples in this temperature range is related to the samples that are in the temperature group of -1.6 to $-2{ }^{\circ} \mathrm{C}$. 
According to studies performed on the samples, salinity of the fluids involved varies from 0.97 to more than $7 \% \mathrm{Wt}$ $\mathrm{NaCl}$. The diagrams of the studied samples show the highest frequency of salinity percentage in the numerical range of 0.97-1.37 as well as 3.67-4.07 in $\mathrm{NaCl} \mathrm{Wt \%} \mathrm{(Fig.} \mathrm{8).}$

\section{HEATING}

The results showed that vapor rich fluids involved are not a good indicator for measuring microthermometry of other fluids, so that repeated measurements several times on this type of fluids have completely different results. This is most likely due to the non-closure of the thermodynamic system of this type of fluid involved (Roedder \& Bodnar). Based on stratigraphic reconstruction of the area, if it is determined that pressure and temperature were not high at the time of crystal formation, this temperature will be mineralization temperature. However, if it is found that the crystal has undergone compression at the time of formation, pressure corrections will be applied after determining salinity and using special diagrams [30].

In the studied samples, homogenization temperature of the two-phase fluids involved was measured by converting vapor to liquid, and in samples containing high vapor, conversion of liquid to vapor was measured. Histogram of homogenization temperature varies from 143 to $330^{\circ} \mathrm{C}$. The highest frequency of homogenization temperature of the studied samples is shown in the temperature range of about 200 to $220^{\circ} \mathrm{C}$ (Fig. 9).

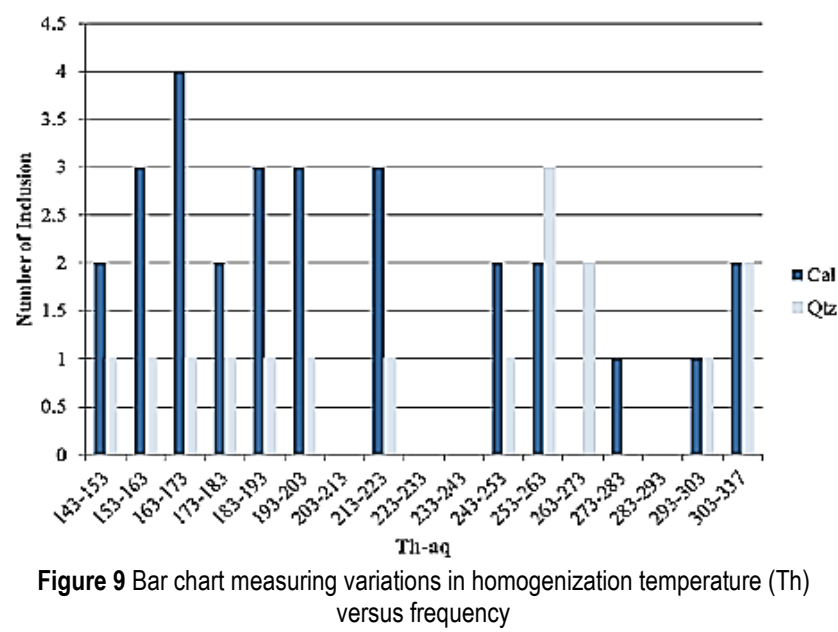

\section{PRESSURE, DENSITY AND DEPTH OF FLUIDS INVOLVED}

Homogenization temperature data, together with fluid Salinity data, determine fluid density approximately at the time of fluid entrapment. Density changes are especially important with respect to fluid flow mechanisms and evolution of specific changes in fluid density, especially in systems that can interrupt the fluid flow process. Data on salinity and homogenization temperature of the studied samples were matched with the diagram adapted from Bodnar and the result is presented as a diagram. According to this diagram, density of fluids is less than $0.6 \mathrm{~g} / \mathrm{cm}^{3}$ to more than $0.9 \mathrm{~g} / \mathrm{cm}^{3}$. The most populous group of fluid inclusions studied are in the density range of $0.87 \mathrm{~g} / \mathrm{cm}^{3}$ to more than $0.90 \mathrm{~g} / \mathrm{cm}^{3}$. According to homogenization temperature and density, depth and pressure of fluid formation can be determined. After matching the temperature-density data of the inclusions with Fig. 10, the process of fluid formation shows a pressure of about 20-200 bar to the ground.

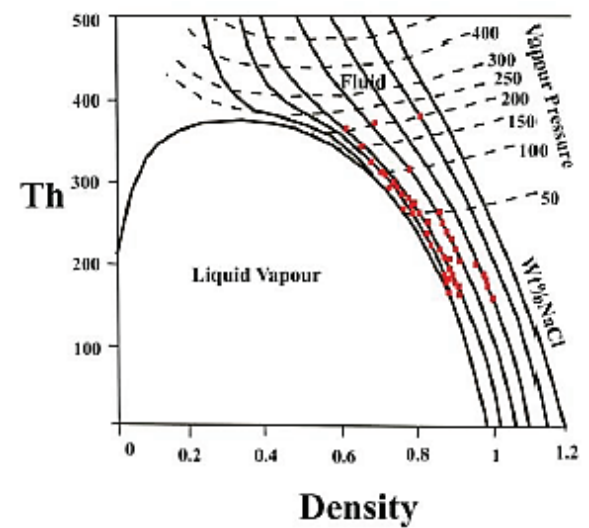

Figure 10 Temperature-density diagram to determine the amount of pressure with respect to salinity

\subsection{Determination of Mineralization Type}

Homogenization temperature and salinity are two main parameters in thermometric studies. Although properties of reserves are not a function of temperature and fluid salinity, the relationship between mineral and natural changes of these two parameters have led to most interpretations based on them. The main classes of mineral deposits occupy ranges in the homogenization temperature-salinity space, which indicates the basic properties of the fluids involved in their formation and are confined entirely between the halite saturation curve and critical curve for pure solution [34]. In Wilkinson [34] diagram, information on Th and salinity of different types of reserves are combined. After matching the Th dispersion-salinity diagram of fluid inclusions in the region with this diagram, most of the samples are in the range of epithermal reserves (Fig. 11).

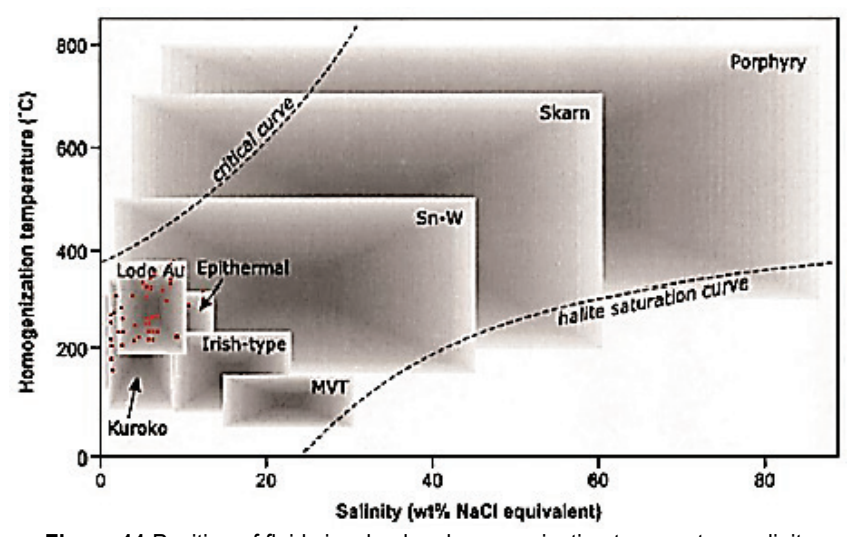

Figure 11 Position of fluids involved on homogenization temperature-salinity diagram of various mineral reserves 
10 GENERATIVE MODEL

In order to compare and determine the type of mineralization and generative model of Chah Mura copper deposit, the deposits formed in volcanic rocks were studied and compared.

\subsection{Michigan Copper Deposits}

Keweenaw-type copper deposits, also known as Michigan copper deposits, are found on the keweenaw Peninsula (northern Michigan). In these deposits, natural copper is the main mineral and calcocite and digenite are present, both of which have high metal to sulfur ratios. Natural copper in these deposits is associated with silver, which also confirms the low partial pressure of sulfur. Mineralization has taken place within basaltic rocks with amygdaloidal-tholeiitic nature as well as in the context of interlayer conglomerate layers. Manto andesitic copper deposits such as Peru and Chile and Arizona may be associated with Michigan copper ores found in basalts and conglomerates. The Calumet-Hecla copper ores on the keweenaw Peninsula in northern Michigan are examples of low-temperature hydrothermal ores that have been transferred to their current location through impermeable conglomerates and fragmented areas of low-slope lava flows. Butler and Burbank [35] point out that basalts are of Precambrian and continental tholeiitic type and have also received conglomerate sediments in areas with volcanic activity.

Due to abundance of open space filler texture compared to open space filler texture compared to substitution texture and lack of alteration, it shows very low pressures and low temperatures. The idea behind generation of the Michigantype mineralization is the epigenetic theory of such reserves. Stoiber and Davidson [36], in their field and laboratory studies, concluded that transformation of lavas at depth caused the alteration of basalt into pompoleite-perhonitechlorite and the release of copper and other chemical structures.

\subsection{Andesitic Copper Deposits}

Veins, veinlets, and bubbles of species resulting from accommodation of cavities and sprays of free copper and silver, chalcocite, and Bornite, and to a lesser extent chalcopyrite, are also found in Middle Mesozoic to Pliocene calc-alkaline volcanic rocks in the American Cordillera. Economic accumulations of this type of ore have been seen so far in Chile and Bolivia (Kuroko taype deposit). These copper manto deposits are generally tens of meters thick and extend up to several kilometers along their direction (in fact, the copper manto deposits were considered to be called andesitic copper deposits). Surface areas of andesitic, dacite, and latite flows, cuts, and ignembrites have been more suitable hosts. As porosity and permeability of these rocks decreases downwards, the grade of copper also decreases. Alteration manifests itself only in the form of slight silicification, carbonation and sometimes pyritization.
Mineralogical, textural characteristics and mineralization host rock in Chah Mura copper deposit, which occurs in volcanic rocks with a combination of basalt andesite and trachyandesic basalt. Its geochemical characteristic, that is, high levels of copper-silver and, in general, a review of these properties, immediately recalls the reserves of the Michigan-type keweenaw Peninsula, USA; by studying more, we will find the differences between the two. Lack of sulfur in formation of copper reserves is unusual. Most copper deposits contain natural copper, but copper deposits are found only in the oxidized zone. It is usually associated with cuprite, tenorite and other secondary copper minerals such as malachite, chrysocolla, azurite, etc. However, natural copper is the main mineral in the Michigan Type deposit. In this deposit, the size of amygdala and veinlets filled with natural copper sometimes reaches $10 \mathrm{~cm}$. In the Michigan type, natural copper ranks first in mineral paragenesis. Other minerals are oxide minerals, including cuprite, tenorite, and chrysocolla. In the group of copper minerals in the Michigan type, no sulfide mineral is found, while in the Chah Mura, the identified copper minerals are copper sulfide minerals and natural copper mineral is present in small amounts along with copper oxide minerals (cupritetenorite). Perhaps this is the obvious difference between the Chah Mura and Michigan copper generation. There is another obvious difference between the two deposits. The difference is in the host rock of the Michigan deposit and mineralization of the Chah Mura. In the Michigan deposit, the host rock has been altered to the extent of the prehnitepompoleite facies, while no trace of alternation is seen in mineralization of Chah Mura copper. This difference may not seem significant at first glance, but when we look deeper into this, we notice a difference in the genetic model of the two reserves. In the Michigan deposit of the keweenaw Peninsula, USA, host rock alternation has led to the formation of the deposit fluid, which has deposited natural copper ores in a sulfur-free environment. Regarding the origin of Chah Mura mineralization, it seems that mass-dependent hydrothermal solutions play a role by leaching copper from host units and enrichment.

\subsection{Volcanic Redbed Deposits}

This type of copper mineralization has typically occurred from Proterozoic to Tertiary. Mineralization host rocks include mafic to felsic lavas, especially tuff, cut lavas, and associated sedimentary rocks such as amygdaloidal basalts, conglomerates, sandstones, and so on. In terms of composition, volcanic rocks cover a range from basalt to rhyolite. Some deposits have a flat structure, some are stratabound zones, and others are controlled by intersecting structures and stratigraphy.

The by-product of copper in this type of reserves is silver. The main minerals of copper are chalcocite, bornite and natural copper. Mineralization has occurred sporadically, in veins, amygdaloidal fillers and fractures. These deposits are typically found at tectonic sites of intracontinental rifts with superficial flood basalt sequences (in contact with open air) and near the plateau along with islands and continental 
arc volcanoes. Low to medium latitude continental to lowdepth marine volcanic sites and arid to semi-arid environments are typical of such reserves.

\subsection{Manto Copper Deposits}

These deposits are the result of hydrothermal replacement process in andesites and sometimes rhyolites. Manto deposits are a group of deposits that are usually stratigraphic and consistent with stratification and within layers or lavas. The main minerals are copper, chalcocite and bornite. Mineralization in this group usually occurs in volcanic layers that are accompanied by dikes, intrusive rocks and sill with gabbrodiorite composition, and unlike other types of deposits, the absence or lack of hydrothermal phenomena of the host rock is one of their obvious features. Manto copper deposits occur mainly near subvolcanic masses with basaltic intermediate composition, but intrusions are often non-mineralized and some have delayed copper minerals. According to age measurement data, it is believed that mineralization is primary sulfide; however, due to stratigraphy, volcanic rocks appear to have formed epigenetically after the deposition and are associated with diorite-type intrusions.

The presence of infertile andesitic dikes injected after mineralization has been reported in the Manto copper deposits, including ... and other Manto deposits in Chile. In Manto copper deposits, the most important alterations are chlorination, epidotization, albitization, silicification, calcification, sphenification, and zeolitization. The presence of negative $\mathrm{Eu}$ in the trace element process is common as in most Manto copper deposits. The mineralization of Chah Mura copper is similar to Manto copper deposits due to paragenetic sequence, texture, construction and alteration and the presence of diorite subvolcanic masses and sterile andesitic dikes in the mineral range as well as the host rock.

\section{CONCLUSIONS}

According to the results, the pattern of rare and trace earth elements that are enriched of LILE and LREE and depleted from HFSE and HREE indicate the characteristics of volcanic arc rocks associated with subduction zone and calc-alkaline magmas. Among the elements, only the amount of copper in the field of $E^{\text {ta }}$ and $E^{\text {an }}$ rocks and subvolcanic masses was higher than normal and other base metals were low. It should be noted that the element copper does not correlate with any of the base metal groups such as lead and zinc, indicating that they do not accompany copper in mineralization, which helps us to obtain the mineralization type. It should be noted that the correlation matrix of copper with silver, arsenic and sulfur is good and this shows that these elements can also accompany the mineralization of copper. The presence of copper sulfide minerals reveals its genetic link with sulfur in mineralogical examination. No specific minerals were found for the presence of silver and arsenic in the study of microscopic sections. It should be noted that elements such as silver and arsenic may be present in the network of other minerals, such as chalcopyrite or chalcocite, and it is best to have a microprop electron analyze to ensure. X-ray diffraction results show the presence of arsenic element next to copper in the structure of an arseniccontaining copper mineral with the chemical formula $\left(\mathrm{Cu}_{3} \mathrm{AsSe}_{4}\right)$.

In the samples of Chah Mura area, based on the constituent phases, 4 types of fluids are involved and based on the origin, two types of primary $(\mathrm{P})$ and secondary $(\mathrm{S})$ can be distinguished. The homogenization temperature is 143 to $330^{\circ} \mathrm{C}$ and the fluid density in these studies is less than 0.60.9 . Examination of fluid inclusions shows that their salinity varies from 1 to more than $7 \%$ by weight of $\mathrm{NaCl}$, which can indicate the presence of fluids with different salinity. The maximum salinity range is $0.97-1.37$ and 3.67- 4.07. Based on the diagram of pressure and depth changes against temperature-salinity and the presence of carbonate minerals such as malachite, azurite and calcite, which indicate the presence of $\mathrm{CO}^{3-}$ or $\mathrm{HCO}^{-3}$ anion in fluids, is evidence of the role of atmospheric fluids in copper mineralization as a result of dilution caused by mixing magmatic-hydrothermal fluids with atmospheric waters. Based on data of homogenization temperature and salinity as well as petrographic results, the fluids involved in the area are in the epithermal category.

\section{REFERENCES}

[1] Mason, B. \& Moor, C. B. (1982). Principles of geochemistry, Jonh Wiles \& Sons Inc.

[2] Barnes, H. J. (1979). Solubilities of ore minerals. Geochemistry of hydrothermal ore deposits, 404-460.

[3] Agha Nabati, A. (2004). Geology of Iran. Geological Survey \& Mineral Explorations of Iran.

[4] Nabavi, M. H. (1976). An introduction to the geology of Iran, Geological Survey of Iran.

[5] Alavi, M. (1991). Sedimentary and structural characteristics of the Paleo-Tethys remnants in northeastern Iran. Geological Society of America Bulletin, 103(8), 983-992. https://doi.org/10.1130/00167606(1991)103<0983:SASCOT>2.3.CO;2

[6] Nogole-Sadat, M. A. \& Almasian, M. (1993). Tectonic map of Iran in 1: 1000, 000 scale. Geological survey of Iran.

[7] Shamanian, G. H., Hedenquist, J. W., Hattori, K. H., \& Hassanzadeh, J. (2004). The Gandy and Abolhassani epithermal prospects in the Alborz magmatic arc, Semnan province, Northern Iran. Economic Geology, 99(4), 691-712. https://doi.org/10.2113/gsecongeo.99.4.691

[8] Houshmandzadeh, A. (1979). Evolution of the geological phenomena of Torud (Precambrian to the present day). Geological Survey \& Mineral Explorations of Iran.

[9] Takin, M. (1972). Iranian geology and continental drift in the Middle East. Nature, 235(5334), 147-150. https://doi.org/10.1038/235147a0

[10] Mohajjel, M., Fergusson, C. L., \& Sahandi, M. R. (2003). Cretaceous-Tertiary convergence and continental collision, Sanandaj-Sirjan zone, western Iran. Journal of Asian Earth Sciences, 21(4), 397-412. https://doi.org/10.1016/S1367-9120(02)00035-4

[11] Ghasemi, A. \& Talbot, C. J. (2006). A new tectonic scenario for the Sanandaj-Sirjan Zone (Iran). Journal of Asian Earth Sciences, 26(6), 683-693. https://doi.org/10.1016/j.jseaes.2005.01.003 
[12] Shahabpour, J. (2007). Island-arc affinity of the central Iranian volcanic belt. Journal of Asian Earth Sciences, 30(5-6), 652665. https://doi.org/10.1016/j.jseaes.2007.02.004

[13] Emami, M. H. (2001). Magmatism in Iran. Geological Survey \& Mineral Explorations of Iran.

[14] Abdalian, S. (1953). Le tremblement de terre de Toroude en Iran. La Nature, 81(3222), 314-319.

[15] Shirokova, E. I. (1962). Stresses effective in earthquake foci in the Caucasus and adjacent districts. Izv. Akad. Nauk. USSR, Ser. Geophiz, 10, 809-815.

[16] Berberian, M. (1979). Discussion of the paper AA Nowroozi, 1976 "Seismotectonic provinces of Iran". Bulletin of the Seismological Society of America, 69(1), 293-297.

[17] Khademi, M. (1990). Structural features and tectonic status of Torud region (south of Damghan). PhD Thesis, Shahid Beheshti University, Department of Earth Sciences.

[18] Rashidnejad, A. (1993). Investigation of lithological developments and its relationship with gold mineralization in Baghu region (south-southeast of Damghan). MA report, Tarbiat Moallem University, Department of Science.

[19] Borna, B., \& Eshgh Abadi, M. (1998). Evaluation and exploration of lead and zinc deposits and indices in Semnan province. Prganization of Industry, Mining and Trade of Semnan Province.

[20] Araghi, A., Martinez, C. J., Adamowski, J., \& Olesen, J. E. (2019). Associations between large-scale climate oscillations and land surface phenology in Iran. Agricultural and Forest Meteorology, 278, 107682. https://doi.org/10.1016/j.agrformet.2019.107682

[21] Bazin, D. \& Hubner, H. (1969). Copper deposits in Iran: Report No. 13. Geological Survey of Iran, 190.

[22] Adabi, M. H. (2006). Comprehensive designation and classification of sedimentary, igneous and metamorphic rocks. Ferdosi University of Mashhad.

[23] Kuno, H. (1968). Origin of andesite and its bearing on the island arc structure. Bulletin Volcanologique, 32(1), 141-176. https://doi.org/10.1007/BF02596589

[24] Rollinson, H. R. (2014). Using geochemical data: evaluation, presentation, interpretation. Routledge. https://doi.org/10.4324/9781315845548

[25] Zarasvandi, A., Liaghat, S., \& Zentilli, M. (2005). Geology of the Darreh-Zerreshk and Ali-Abad porphyry copper deposits, central Iran. International Geology Review, 47(6), 620-646. https://doi.org/10.2747/0020-6814.47.6.620

[26] Zhang, H., Shi, X., Li, C., Yan, Q., Yang, Y., Zhu, Z., ... \& Zhao, R. (2020). Petrology and geochemistry of South MidAtlantic Ridge $\left(19^{\circ} \mathrm{S}\right)$ lava flows: Implications for magmatic processes and possible plume-ridge interactions. Geoscience Frontiers, 11(6), 1953-1973. https://doi.org/10.1016/j.gsf.2020.06.007

[27] Maanijou, M., Aliani, F., Miri, M., \& Lentz, D. R. (2013). Geochemistry and petrology of igneous assemblage in the south of Qorveh area, west Iran. Geochemistry, 73(2), 181196. https://doi.org/10.1016/j.chemer.2013.04.001

[28] Seewald, J. S. \& Seyfried Jr, W. E. (1990). The effect of temperature on metal mobility in subseafloor hydrothermal systems: constraints from basalt alteration experiments. Earth and Planetary Science Letters, 101(2-4), 388-403. https://doi.org/10.1016/0012-821X(90)90168-W

[29] McCuaig, T. C. \& Kerrich, R. (1998). P-T-tdeformation-fluid characteristics of lode gold deposits: evidence from alteration systematics. Ore Geology Reviews, 12(6), 381-453. https://doi.org/10.1016/S0169-1368(98)80002-4
[30] Ermakov, N. P. \& Roedder, E. W. (Eds.). (1965). Research on the nature of mineral-forming solutions: with special reference to data from fluid inclusions (Vol. 22). Pergamon.

[31] Shepherd, T. J., Rankin, A. H., \& Alderton, D. H. (1985). A practical guide to fluid inclusion studies. Blackie.

[32] Pirajno, F. (2008). Hydrothermal processes and mineral systems. Springer Science \& Business Media. https://doi.org/10.1007/978-1-4020-8613-7

[33] Haj Alilo, M. (2000). Geothermometry of fluid inclusions. Tehran: Payam Nour University.

[34] Wilkinson, J. J. (2001). Fluid inclusions in hydrothermal ore deposits. Lithos, 55(1-4), 229-272. https://doi.org/10.1016/S0024-4937(00)00047-5

[35] Butler, B. S. \& Burbank, W. S. (1929). The copper deposits of Michigan (Vol. 144). US Government Printing Office. https://doi.org/10.3133/pp144

[36] Stoiber, R. E. \& Davidson, E. S. (1959). Amygdule mineral zoning in the Portage Lake Lava series, Michigan copper district; Part 1. Economic Geology, 54(7), 1250-1277. https://doi.org/10.2113/gsecongeo.54.7.1250

\section{Authors' contacts:}

\section{Fatemeh Baseri}

Faculty of Basic Sciences, Department of Geology, North Tehran Branch, Islamic Azad University, Vafadar Blvd., Shahid Sadoughi St., Hakimiyeh Exit, Shahid Babaee Highway, 1651153311 Tehran, Iran

\section{Arash Gourabjeri Pour \\ (Corresponding author) \\ Faculty of Basic Sciences, Department of Geology, North Tehran Branch, Islamic Azad University, Vafadar Blvd., Shahid Sadoughi St., Hakimiyeh Exit, Shahid Babaee Highway, 1651153311 Tehran, Iran agourabjeripour@chmail.ir}

\section{Nima Nezafati}

Faculty of Basic Sciences, Department of Geology, North Tehran Branch, Islamic Azad University, Vafadar Blvd., Shahid Sadoughi St., Hakimiyeh Exit, Shahid Babaee Highway, 1651153311 Tehran, Iran 